\title{
THE EFFECT OF PICTURE SERIES AND STUDENTS LEARNING MOTIVATION ON WRITING COMPETENCY
}

\author{
N.L.P.J. Rany ${ }^{1}$, P.K. Nitiasih ${ }^{2}$, M.H. Santosa ${ }^{3}$ \\ ${ }^{123}$ English Language Education, Universitas Pendidikan Ganesha, Singaraja \\ e-mail: puturany92@gmail.com , kertinitiasih@undiksha.ac.id, mhssantosa@undiksha.ac.id
}

The purposes of this research are of three folds: first, to closely look into whether there are significant differences in writing achievement; second, the learning motivation of students in writing; third, significant differences in writing achievement between the students with highlearning motivation taught using Picture series technique and those taught by using the conventional technique; and the significant differences in writing achievement between the students with low-learning motivation taught using Picture Series technique and those taught by using conventional technique. This research uses writing achievement test to assess the students' score in writing. The writing achievement test was administered at the end of teaching learning process to obtain information on the effect of the treatment upon the students' writing achievement. In this research, it was discovered that there was significant effect of picture series on writing competency as well as the effect of writing competency on high and low learning motivation students who were taught by using guided writing strategy and the conventional strategy.

\section{Keywords: English Education; Learning Motivation; Writing Competency}

\section{INTRODUCTION}

English is a universal language that is widely spoken around the world and is becoming a primary key to communication. In addition, English language in Asian countries, including Indonesia, is becoming one of the compulsory school subjects to learn. Most schools now offer English as a compulsory subject, ranging from primary to higher education. In addition, the English subject was formulated in the Secondary School's standard of competency and basic competency, covering four facets of associated English skills, namely: listening, speaking, reading, and writing. In most schools in Indonesia, those four skills must be learned and mastered by students.

Developing communicative competence is the key goal of teaching English to students in Indonesia. According to one of the eight Indonesian National Education System Content Requirements, one of the goals of teaching English as a foreign language in Indonesia is to establish oral and written communicative skill in the target language (L2). The Eight Content Standard of the Indonesian Education System also means that students can reach a degree of functional literacy where students can use English on a regular basis, such as reading newspapers, manuals or directions (Regulation of the Minister of National Education of the Republic of Indonesia No. 20 of 2007 on Education Assessment Standards). Teaching English in Indonesia is aimed at improving the skills of students that cover all four language skills in order to achieve the goals: listening, speaking, reading, and writing skills.

Writing is one of the skills that students need to learn to enable students to write in English on any of the topics in different types of writing formats. It is often frustrating to encourage students to write in English, as students lack English skills. However, writing is a hard job and takes a lot of work to generate high-quality English writing at the same time; hence, teachers should motivate students to frequently and continuously practice writing. Students must have good writing skills in order to compose adequately. They should be able to properly organize concepts, create phrases, use punctuations and word choices. A instructor should use an appropriate technique in the teaching learning process to convey the subject material to the learners.

In addition, writing is one of the four language skills that are just as significant as the other three abilities; reading, listening, and speaking. Students are able to communicate through sentences, phrases and word diction in writing skills to represent their feelings and 
convey messages to the readers. It is a good idea for students to learn to write in a simple format in order to increase the student's understanding of how important English writing skills are, as important as the other three English language abilities. These four skills have been the key focus of teaching and learning English as a foreign language (Harmer,2007).

Nunan (2007) notes that writing is the process of thinking to invent concepts, thinking about how to express their feelings and emotions in good writing, and clearly organizing the ideas into statements and paragraphs. Most students, however, find it difficult to write in English, especially for junior high school students. They find it difficult to articulate their own thoughts and construct words into phrases; they appear to be passive students and are unable to take part in any of the classroom's writing lessons. Most learners feel that it is too hard for them to write English and it makes them feel demotivated and lose their passion for learning to write in English. That is why a good way to teach English is to raise their interest in learning English, particularly writing, through the appropriate strategy or teaching media.

Furthermore, writing is an important skill that requires intense daily practice and a lot of effort. It means that the students should go through a complicated process to produce a successful writing. Students are encouraged to use the following four steps to do this, namely: pre-writing, drafting, revising, and editing. Students brainstorm the writing topics at the pre-writing stage and then bring some potential topics into the drafting. Students describe such principles in drafting and attempt to arrange them into a collection of phrases to become paragraphs. If students are good in putting them in several paragraphs, the next step is the examination. Students need to read the whole ideas in the revising process and look at the arrangement of ideas to see if minor revision is required. Editing is the latest move. After discovering that in many paragraphs, all ideas are well structured, then students finalize with spelling and grammar errors. At this point, in order to have good writing, learners have more opportunities to see how it looks. The writing can then be written without errors and with good quality (Wich at al,2006).

Motivation for learning is very crucial in teaching and learning foreign languages, including English language. Students might not be able to establish strong piece of writing without feeling inspired and more importantly the willingness to do so. Motivation is the most important component where learners fail or achieve success, if students are getting motivated and inspired, they will be easily composing a piece of writing, according to Brown (2000). Motivation therefore also means in certain cases as a sequence of an initiative so that the students want to do something and if they are not interested or hate it, they will try to ignore the feeling and do it. In order to make students feel inspired, teachers or educators play an important role. In this case, it is recommended that teachers recognize every single improvement of learners throughout the development process and inspire them to do even better throughout the process of acquiring writing skills. According to Ormord (2014), motivation has six impacts on the learning of students and increases commitment and energy, increases task initiation and persistence, impacts the cognitive process, decides the implications of strengthening and punishing, and sometimes improves efficiency.

Teaching strategies should also be considered in addition to the causes of motivation that impact writing skills. According to Wikipedia (2016), a teaching method contains the concepts and techniques used to provide instructions. They can involve clarifying, revealing, and collaborating. The teaching method is clarified by presenting a spoken description of the topic being taught and learned. Demonstrating is a teaching method that is similar to written storytelling and examples in order to allow students to react emotionally to the information provided. Collaboration encourages students to engage positively in the learning process, such as debating, talking to each other, and listening to various other points of view.

The practice of emerging media for teaching will increase the interest of students in learning English. The students cannot be quickly bored with the teacher's content because the teacher provides a number of diverse tasks and uses multiple learning strategies. The Image Series is one of the learning styles for educators. This may be an alternative way to teach secondary students English. Not only does the Picture Sequence explain reality, but it also shows the general structure of a subject and the relative meaning of individual parts of it.

Suharta (2001), who conducted a study on the learning and teaching of elementary students in Bali, explains that teachers typically pursue step-by-step practices in their 
teaching: the activities involve the implementation of learning objectives, the description and success of such lessons, the consistency of texts, often sequential and non-conceptual, and content in the spiral method used in the tutorial that focuses on the In the teaching - learning activities, these circumstances are not so noticeable in junior high schools.

The researcher studied more closely how the teacher instructed students based on the observation of the researcher in SMP PGRI 2 Denpasar and also examined how the lesson plan was developed and implemented in classrooms. The material was about how an announcement should be written. Using examples, the students listened to the teacher's description and guidance on the content of the announcement, and then the students tried to search for the content and the announcement details. The students would then be asked to write a section of the announcement and do the exercises. It can be inferred that the class started with a brief description of the writing philosophy of a kind of genre, illustrating writing and finishing with exercises. The other result revealed that, in writing, most of the students made the same grammar errors. In organizing their thoughts, they considered the main sentence or supporting sentences to be very difficult.

The teachers were found to use traditional methods to help students write a piece of writing. This will impact the capacity of the student to generate creative writing. The traditional technique is used by the teacher to assist the students, as in the strategy of the image sequence, it is not carried out step by step. The students mainly work on their job and the position of the teacher only gives scores of assessments. The score is poor when students do not do well. The instructor should use the correct approach to make things easier.

The researcher discovered several research using guided writing in order to support certain explanations. The researcher found Suryaningsih's thesis (2010). The results of her research in SMPN 4 Mendoyo entitled "The Effect of Guided Writing and Learning Styles Toward Writing Competency," showed that there was a substantial gap in writing skills between students who were taught guided writing and those who were taught using traditional writing techniques. In addition, since it is very effective, the implementation of directed writing in research needs to be improved in the teaching and learning phase. The Department of Children, Schools and Families of the National Primary Strategy (2007) also claimed that directed writing provides an addition to the critical component of the healthy writing curriculum. Kellog (in et al.,2011) found out that proper writing techniques will increase the efficiency of writing and reduce the overload of attention. In addition, writing success is often encouraged, and teachers may play an important role in helping students develop viable strategies to prepare themselves for drafting, revising, and editing (Lan, et al.,2011).

A research by Handayani et al. (2013) also aimed to investigate whether the implementation of the driven writing strategy and the encouragement for student achievement had a substantial impact on the writing skills of students in senior high school. The outcome reveals that, first, there was a substantial difference between the students who were taught using picture series writing strategy and traditional writing strategy in the students' writing skills. Second, there would be a major interactional impact on the competency of students writing between the techniques applied and the encouragement of the students to achieve. Third, when they are taught by picture series writing and traditional strategy, there would be a substantial difference in the students writing competency between the students who had high motivation for achievement. Fourth, when they are taught using picture series writing strategy and traditional strategy, there would be a substantial difference between the students writing competency of the students who had low motivation for achievement.

In particular, the teachers and students themselves, such as the teaching and learning style, are affected by the output of teaching and learning to write in English. The external factor is the teaching technique, which means that it relies on the success of the teacher in applying the technique and the learning style as the inward factor of the students themselves to achieve better results. These variables affected the learning process in SMP PGRI 2 Denpasar. Based on the aforementioned context, certain concerns can be identified; students found it difficult to coordinate their thoughts before pouring them into prose. This condition 
also suggested that in writing, the students had inadequate techniques. The biggest challenges came from planning the idea.

Furthermore, many students have diverse contexts for learning English. Most of them come from national primary schools that have very basic acquisition of the English language. Hence, they also have the same issues as they are in junior high school. Writing capabilities are one of the predominant issues. In brief, when writing a long essay, they have difficulty in building sentences. The key difficulties that the students have had in English writing can be seen on assessment in English class in SMP PGRI 2 Denpasar and during teaching learning process. In order to create a piece of writing and arrange their thoughts, the students took a very long time. Once they wrote it in paragraphs, they did not make any revisions. The teacher typically began the class by providing a brief description of writing concepts, a kind of genre, explaining writing and finishing by performing exercises. It is impossible for students to follow this learning approach and they have problems arranging coherence expressions. In addition, it is possible to consider the learning process issues in SMP PGRI 2 as follows:

First, there was a shortage of vocabulary at SMP PGRI 2 grade 8 students and they could only pronounce and remember the individual words without conveying the message what the teacher is transmitting. Second, Students have not been able to write a piece of writing and grasp a longer paragraph. It was difficult for students to reflect on thoughts and bring them into a paragraph. Students lacked confidence to learn how to compose. And third, the teacher's writing instruction approach concentrated on the description of the writing paragraph.

\section{RESEARCH METHOD}

The current study dealing with the effect of the student's learning encouragement of Picture series on the writing skills of the students at SMP PGRI 2 Denpasar seventh-grade students in the academic year 2016/2017. This analysis is an experimental study based on the study problem, since it is to analyze the theory to find the answer to the problems based on the theories. In essence, factorial design is an experiment changing design scilicet attention to the probability of the variable moderator affecting the outcome (Sugiyono, 2011).

Since the design was previously stated as being a random design comparison between two categories, the design used at least two groups of samples. In this analysis, only when text forms (i.e. descriptive) were taken from the two groups, group the researcher obtained Image Series and Group II traditional prose. After the treatments had been completed, posttests were conducted at the appraisal stage. The post-test scores of the two groups were taken once for each text form, and then three post-test values were calculated for each group. The findings of the post-test were presented to highlight whether there was a substantial influence on the writing skills of the students between picture series and conventional writing and whether there was a clear distinction between the effect of picture series and conventional writing.

Table 1. Two-Group Comparison Experimental Design

\begin{tabular}{ccc}
\hline Teaching Technique & Picture Series (A1) & Conventional writing (A2) \\
Learning Motivation & & \\
\hline Field Dependent (B1) & A1B1 (30 students) & A2B1 (30 students) \\
Field Independent (B2) & A1B2 (30 students) & A2B2 (30 students) \\
Total & A1B1 + A1B2 & A2B1+ A2B2 \\
\hline
\end{tabular}

Information:

A1

A2

High B1

Low B2

A1B1

A2B1
Community taught using the technique of guided writing.

Community taught using the traditional strategy of writing.

Group of students with high enthusiasm for studying.

Learners with strong learning incentive community

Group of learners with strong learning incentive taught by using technique for image sequence

Group of learners with strong learning motivation taught using traditional 
writing techniques.

\section{the image set.}

A2B2 : Group of learners with poor learning enthusiasm taught using traditional writing techniques.

This model was used on the basis of the premise that the two variables had an influence on the other variable and that the relationship between the independent variable and the variable of the moderator had an effect on the dependent variable.

\section{FINDINGS AND DISCUSSION}

In SMP PGRI 2 Denpasar, there is a significant influence of direct writing on the writing skills of eighth-grade students. The probability value was 0.000 according to the one-way ANOVA test outcome, while the significance value was 0.005 , since the value was smaller than the significant value at 0.05 (Sig $>0.05)$ than should be perceived by the alternative hypothesis. The influence of the picture series on students' writing was based on the results.

Reinforced by the descriptive analysis, the mean written competency test score for students who learned using picture sequence was 83.24 and the mean competency score for writing treated using the conventional writing method was 74.65. It can be concluded from the mean score finding that, according to learning strategy, the group of students taught by using picture series was higher than the students taught by using conventional writing strategy. The conventional approach in the present review applied to one that was normally used by the English instructor at SMP PGRI 2 Denpasar.

There was a reason why the picture series was easier than the conventional writing technique. In the experimental class, the students took several steps; the first stage was to include the related topic in the class. When the subject was only explained by the teacher, the students became less involved. They paid more attention when the teacher showed an illustration.

The conversation was the second step of the teacher, and the students explored several elements related to the photo. When the teacher took this action, the students were able to say something which came to their mind. The learning environment has improved as indicated by the improvement of students' active participation in the classroom. The students worked in a group in this section to find some elements of the subject. They also debated what the text's generic form was with their group.

The third stage was Scrutinizing. The teacher asked the students to ask some questions relevant to the pictures. The students carried their own pictures taken from magazines, papers, posters, and framed photographs. The students then wrote their own questions, which in the paragraph were later formulated. Based on this assignment, the instructor could increase the output of the students' writing.

Brainstorming was the fourth step. The students created their proposals based on the photographs shown or seen in brainstorming. The photo on the stage was the big point. It helped the students to get some helpful phrases while writing their section.

Sketching is the fifth step. This encourages the students to choose as the outline of the paragraph several significant concepts. In this move, the teacher engaged by giving instruction to students. For eg, helping the students to decide what ideas can be placed in the first, second, third, before the last one. Drafting was the next step. Based on the outline they wrote upon entering this level, the students were assigned to compose a draft. The aim of this stage was to create relevant ideas into a paragraph.

The sixth phase was a redesign. After finalizing the draft, learners can rewrite their jobs. They revised their writing based on the instruction in the form of a check-list offered by the instructor. The learners were updated twice in this case. Second, they need to swap work. After that, they return to their classmates' jobs after revision. Second, they have made their own corrections. After the students revised their writing, however, the editing process was the next step. They rewrote their prose based upon the revision. The students predominantly provided several reviews on grammar and mechanics.

Sharing was the last phase. It was an operation for reviewers. Because of the restricted time, only a few students could publish their thesis. The teacher asked the students to 
perform or read their work in front of the class, because the other friends became mindful of their written work. They seemed so happy during the entire activity.

Table 2. The Result of Normality Test

\begin{tabular}{lrlllll}
\hline & \multicolumn{3}{c}{ Kolmogorov-Smirnov $^{\mathrm{a}}$} & \multicolumn{3}{c}{ Shapiro-Wilk } \\
\cline { 2 - 7 } A1 & Statistic & $\mathrm{df}$ & Sig. & Statistic & $\mathrm{df}$ & Sig. \\
\cline { 2 - 7 } A2 &, 148 & 7 &, $200^{*}$ &, 985 & 7 &, 979 \\
B1 &, 255 & 7 &, 186 &, 833 & 7 &, 086 \\
B2 &, 148 & 7 &, $200^{*}$ &, 985 & 7 &, 979 \\
A1B1 &, 270 & 7 &, 133 &, 906 & 7 &, 370 \\
A1B2 &, 148 & 7 &, $200^{*}$ &, 985 & 7 &, 979 \\
A2B1 &, 270 & 7 &, 133 &, 906 & 7 &, 370 \\
A2B2 &, 321 & 7 &, 079 &, 806 & 7 &, 067 \\
\hline
\end{tabular}

*. This is a lower bound of the true significance.

a. Lilliefors Significance Correction

\section{CONCLUSION AND SUGGESTIONS}

Referring to the study findings and discussion discussed in the previous chapter, it can be concluded that: First, the picture series has an immense effect on the competency of writing. The writing achievement of students was higher when they were taught using picture series than when they were taught using the standard method. Compared to the conventional writing approach, it indicates that picture series have had an impact on students' writing skills; second, there is a substantial interactional impact on writing competence between learning techniques introduced at SMP PGRI Denpasar and the learning motivation of eightgrade students on their writing skills; third, there is a significant distinct effects of writing skills on students with high learning motivation among students who are taught using image series and those who are taught using conventional strategy. The image series affected the writing skills of students, especially students with high learning motivation, relative to the conventional writing strategy; and fourth, in writing, there is a huge effect of competency on students with low desire to learn who have been taught using image series and conventional technique. In contrast to the traditional writing strategy, the conventional strategy affected the students' writing skills, especially students with low willingness to read.

Referring to the topic and the result, some recommendations are mentioned as below: first, English teachers are expected to apply for picture series in teaching writing, in particular for students with low motivation. It is due to teaching method delivery traits, activities, and measures that have a greater impact on students with low motivation for learning than students with high motivation for learning. It is also attributed to the use of picture series that, through writing, could help students compose a good paragraph; second, because of the outcome of this report, which demonstrates the students' writing ability, not only the English teacher of eight-grade SMP PGRI 2 Denpasar students, but also other teachers from other schools are encouraged to use picture series in writing class.

This research is limited in term scope and the subject size. For these reasons, it is suggested that further research that examines the effect of the picture sequence on different aspects of learning, such as on students' attitudes, motivation, achievement, etc. Further research also needs to involve bigger sample size for a more generalizable result.

\section{REFERENCES}

Brown, H. Douglas. 2000. Techniques and Principles of LanguageLearning and Teaching. New York: Pearson Education, Inc.

Handayani. Sri, dkk. 2013. Bahasa Indonesia Tulisan dan Penyajian Karya Tulis.Bandung: Kharisma Putra Utama Offiset. (Tidak ada di teks)

Harmer, Jeremy. 2007. The Practice of English Language Teaching. Fourth Edition.Person Longman: Harlow. 
Kellogg,R.T. 2011. Training Writing skills: A cognitive develompment perspective.

Lan,Y.F.,Hung, C.L. \& Hsu, H.J.2011. Effects of Guided Writing Strategies on Students' Writing Attitudes Based on Media Richness Theory. TOJET : The Turkish Online Journal of Education Technology, Volume 10 Issue 4,149.

Nuna, David. 2007. Practical English language Teaching: Young Learners; Textbook for teachers, New York: Prentice hall. (yang ada di teks adalah nunan (2007)

Ormord, J.E. 2014. How Motivation Affects Learning and Behavior. England.Pearson.

Suharta. I Gusti Putu.2001. Penerapan Pembelajaran Matematika Realistik Untuk Mengembangkan Pengertian siswa.

Sugiyono.2011. Metode Penelitian Kuantitatif,Kualitatif dan R\&D. Bandung : Afabeta.

Surianingsih, Ni Komang. 2011. The Effect of Guided Writing and Learning style TowardWritingCompetencyofSeventhGradeStudents'atSMPNegeri4 Singaraja: Program Pascasarjana Universitas Pendidikan Ganesha.

Wikipedia encyclopedia. 210. Competency.Available at: http//en.wikipedia.org/wiki/Competence \%28human resources\%29. Accessed on September2016.

Wich, G., Johston, R R., March, P., Ljungdahl, L., and Holliday, M.2006.Literacy. Reading, Writing, and Children`s Literature. Third Edition. New York: Oxford University Press. 